\title{
Shipborne measurements of Antarctic submicron organic aerosols: an NMR perspective linking multiple sources and bioregions
}

\author{
Stefano Decesari ${ }^{1}$, Marco Paglione ${ }^{1}$, Matteo Rinaldi ${ }^{1}$, Manuel Dall’Osto ${ }^{2}$, Rafel Simó ${ }^{2}$, Nicola Zanca ${ }^{1}$, \\ Francesca Volpi ${ }^{1}$, Maria Cristina Facchini ${ }^{1}$, Thorsten Hoffmann ${ }^{3}$, Sven Götz ${ }^{3}$, Christopher Johannes Kampf ${ }^{4}$, \\ Colin O'Dowd ${ }^{5}$, Darius Ceburnis ${ }^{5}$, Jurgita Ovadnevaite ${ }^{5}$, and Emilio Tagliavini ${ }^{6}$ \\ ${ }^{1}$ Institute of Atmospheric and Climate Sciences, National Research Council of Italy (CNR), I-40129, Bologna, Italy \\ ${ }^{2}$ Institut de Ciències del Mar, Consejo Superior de Investigaciones Científicas (CSIC), ES-08003, Barcelona, Spain \\ ${ }^{3}$ Institute of Inorganic and Analytical Chemistry, Johannes Gutenberg University of Mainz, 55128, Mainz, Germany \\ ${ }^{4}$ Institute of Organic Chemistry, Johannes Gutenberg University of Mainz, 55128, Mainz, Germany \\ ${ }^{5}$ School of Physics and C-CAPS, National University of Ireland Galway, H91 CF50, Galway, Ireland \\ ${ }^{6}$ Department of Chemistry, University of Bologna, 40126, Bologna, Italy
}

Correspondence: Stefano Decesari (s.decesari@isac.cnr.it)

Received: 1 October 2019 - Discussion started: 7 October 2019

Revised: 14 February 2020 - Accepted: 19 February 2020 - Published: 8 April 2020

\begin{abstract}
The concentrations of submicron aerosol particles in maritime regions around Antarctica are influenced by the extent of sea ice. This effect is two ways: on one side, sea ice regulates the production of particles by sea spray (primary aerosols); on the other side, it hosts complex communities of organisms emitting precursors for secondary particles. Past studies documenting the chemical composition of fine aerosols in Antarctica indicate various potential primary and secondary sources active in coastal areas, in offshore marine regions, and in the sea ice itself. In particular, beside the well-known sources of organic and sulfur material originating from the oxidation of dimethylsulfide (DMS) produced by microalgae, recent findings obtained during the 2015 PEGASO cruise suggest that nitrogen-containing organic compounds are also produced by the microbiota colonizing the marginal ice zone. To complement the aerosol source apportionment performed using online mass spectrometric techniques, here we discuss the outcomes of offline spectroscopic analysis performed by nuclear magnetic resonance (NMR) spectroscopy. In this study we (i) present the composition of ambient aerosols over open-ocean waters across bioregions, and compare it to the composition of (ii) seawater samples and (iii) bubble-bursting aerosols produced in a sea-spray chamber onboard the ship. Our results show that the process of aerosolization in the tank enriches primary marine particles with lipids and sugars while depleting them of free
\end{abstract}

amino acids, providing an explanation for why amino acids occurred only at trace concentrations in the marine aerosol samples analyzed. The analysis of water-soluble organic carbon (WSOC) in ambient submicron aerosol samples shows distinct NMR fingerprints for three bioregions: (1) the open Southern Ocean pelagic environments, in which aerosols are enriched with primary marine particles containing lipids and sugars; (2) sympagic areas in the Weddell Sea, where secondary organic compounds, including methanesulfonic acid and semivolatile amines abound in the aerosol composition; and (3) terrestrial coastal areas, traced by sugars such as sucrose, emitted by land vegetation. Finally, a new biogenic chemical marker, creatinine, was identified in the samples from the Weddell Sea, providing another confirmation of the importance of nitrogen-containing metabolites in Antarctic polar aerosols.

\section{Introduction}

The Antarctic continent is one of the last pristine areas of our planet, but its natural ecosystems are now threatened by an acceleration of the effects of global warming. Although at the beginning of the 21st century the signals of climate change looked still weak in the region, the ice-sheet mass loss in Western Antarctica has greatly accelerated in the last 
10 years as the Southern Ocean waters have experienced a clear warming trend (The IMBIE team, 2018). The consequences for Antarctic maritime and coastal environments encompass strengthening of westerly winds, reduction of summer sea-ice extent, shifting geographical ranges of bird communities, expanding terrestrial vegetation, increasing glacier melt, and freshwater formation over land, etc. (Rintoul et al., 2018). As all these specific ecosystem impacts involve factors deemed important for aerosol production in Antarctica (Davison et al., 1996; Schmale et al., 2013; Kyrö et al., 2013; Barbaro et al., 2017), a significant effect of climate change on atmospheric concentrations of aerosols and cloud condensation nuclei $(\mathrm{CCN})$ must be expected to occur by the end of this century. Field studies performed in maritime and coastal areas around Antarctica in the austral summer since the 1990s (Davison et al., 1996) enable us to gather precious information on the multiple feedbacks between atmospheric composition and ecosystems in a warming climate. In summer, the sea ice recedes, allowing wind stress over the oceanic surface and sea spray to occur closer to the continent, hence increasing the production of primary marine aerosols. At the same time, the thinning of sea ice in its marginal zone and the increased intensity of solar radiation allow microalgae to colonize the ice (Fryxell and Kendrick, 1988; Roukaerts et al., 2016). The microbiota produce low molecular weight metabolites as cryoprotectants and osmoregulators, like dimethylsulfoniopropionate (DMSP) and quaternary nitrogen compounds (Dall'Osto et al., 2017). Once released in seawater, such compounds become precursors of atmospheric reactive volatile reactive compounds, such as dimethylsulfide (DMS) and methylamines, which eventually can lead to the formation of secondary aerosols. Indeed, Davison et al. (1996) observed concentrations of DMS south of $60^{\circ} \mathrm{S}$ of more than 4 times higher than in the Atlantic Ocean. DMS and other reactive volatile species are known precursors to the secondary marine aerosol that contribute to the aerosol population in the marine boundary layer together with primary sea-spray particles. Marine aerosols impact global climate by reducing the amount of solar radiation reaching dark surface of the ocean, both directly (through scattering) and indirectly (by modulating cloud formation and lifetime; O'Dowd and de Leeuw, 2007). Furthermore, in polar regions, cloud seeding by marine aerosols transported over glaciated regions also affects the longwave radiation budget (Willis et al., 2018).

During the 2015 PEGASO cruise (Dall'Osto et al., 2017, 2019; Fossum et al., 2018), we conducted continuous atmospheric observations for over $42 \mathrm{~d}$, providing one of the longest shipborne aerosol measurement records in this area of the world. We contrasted the composition of seawater north and south of the Southern Boundary of the Antarctic Circumpolar Current (SBACC), which represents the approximate boundary between the open Southern Ocean and the waters directly affected by sea-ice formation and melt around Antarctica. Dall'Osto et al. (2017) showed that not only did DMSP and DMS occur in greater concentrations in sympagic waters (south of the SBACC), but quaternary nitrogen compounds and methylamines did as well. By contrast, other biological parameters of seawater, like chlorophyll $a$, total organic carbon (TOC), and transparent exopolymeric particles (TEPs), showed higher concentrations in the open Southern Ocean north of the SBACC. Results of bubblebursting experiments conducted on nascent seawater as well as using melted sea ice showed that organic nitrogen and organic carbon were more abundant in the aerosol in the latter case. Moreover, the production of organic-rich particles was better traced by markers of the ice biota, such as mycosporines, than by macro-tracers of biological productivity (chlorophyll). These results indicate that not only productivity per se but also the composition and ecophysiological state of the microbiota affect the production of aerosol precursors in seawater. Indeed, the observations of organic nitrogen in the aerosol - carried out using both online and offline chemical methods - pointed to strong sources in the area of the Weddell Sea which, at the time of the field campaign, was heavily covered by sea ice.

These findings contribute to the growing observational dataset of aerosol chemical compositions for coastal Antarctic and sub-Antarctic marine areas, which hosts reports of chemical analysis performed on filter and impactor samples (Davison et al., 1996; Virkkula et al., 2006), as well as the results of online aerosol mass spectrometric techniques acquired in recent years (Zorn et al., 2008; Schmale et al., 2013; Giordano et al., 2017). All the measurements performed so far agree, showing a reduction of sea-salt aerosols from the Southern Ocean to the coasts of Antarctica, while secondary species including non-sea-salt sulfate and methanesulfonate (MSA) occur at relatively higher concentrations at higher latitudes as a result of the DMS emissions from marginal ice zone waters. Open questions remain about (a) the amount of non-MSA organic matter in Antarctic air masses, and (b) its origin (either primary or secondary). Recent studies also suggests that blowing snow at high wind speeds may be an important yet hitherto underestimated source (Giordano et al., 2018; Frey et al., 2020), adding complexity to the source apportioning of organic aerosols. First observations of organic carbon (OC) in size-segregated aerosol samples collected at a coastal site in the Weddell Sea (Virkkula et al., 2006) showed that MSA represented only a few percent of the total OC in the submicron fraction. In contrast with these findings, aerosol mass spectrometric (AMS) measurements showed that the organic matter in submicron aerosols transported in Antarctic air masses was almost totally accounted for by MSA, while non-MSA organic compounds were associated with aerosols originating from highly productive waters in the Southern Ocean (Zorn et al., 2008). Non-MSA OC can form also from insular terrestrial biomass emissions (Schmale et al., 2013). In particular, organic particles emitted from seabird colonies contain large amounts of nitrogen with MS spectral fingerprints overlapping with those of nat- 
ural amino acids. In the paper by Liu et al. (2018), Fouriertransform infrared (FTIR) spectroscopy was employed to probe the sources of particulate organic compounds at another coastal Antarctic site, and the results point to a contribution of marine polysaccharides transported in sea-spray aerosols. Finally, detailed organic speciation using offline analytical techniques with high sensitivity and selectivity suggest further contributions from marine proteinaceous material, terrestrial lipids, and secondary organic compounds (Bendle et al., 2007; Barbaro et al., 2015, 2017), but it is unclear how much the concentrations of compounds occurring at $\mathrm{pg} \mathrm{m}^{-3}$ relate to that of bulk organic matter. We present here the organic characterization of Antarctic aerosol employing proton nuclear magnetic resonance $\left({ }^{1} \mathrm{H}-\mathrm{NMR}\right)$ spectroscopy. NMR spectroscopy has been used for decades in several fields of biogeochemistry for its ability to fingerprint several classes of biomolecules and natural organic matter in aquatic and terrestrial environments (e.g., Pautler et al., 2012; Hertkorn et al., 2013). In this study, which focuses on the analysis of samples collected during the PEGASO 2015 cruise, we contrast the NMR composition of submicron aerosol samples with that of seawater samples and bubblebursting aerosols. The results provide new hints on the origin of non-MSA aerosol organic matter in fine aerosol particles in the Antarctic and sub-Antarctic marine environment.

\section{Experiment}

\subsection{Ambient aerosol sampling on filters}

The PEGASO (Plankton-derived Emissions of trace Gases and Aerosols in the Southern Ocean) cruise was conducted onboard RV Hesperides in the regions of Antarctic Peninsula, South Orkney Islands, and South Georgia Island from 2 January to 11 February 2015 (Dall'Osto et al., 2017). A high volume sampler (TECORA ECO-HIVOL, equipped with Digitel $\mathrm{PM}_{1}$ sampling inlet) collected ambient aerosol particles with $D_{\mathrm{p}}<1 \mu \mathrm{m}$ on pre-washed and pre-baked quartzfiber filters, at a controlled flow of $500 \mathrm{~L} \mathrm{~min}^{-1}$. Sampling was allowed only when the samplers were upwind the ship exhaust with a relative wind speed threshold of $5 \mathrm{~m} \mathrm{~s}^{-1}$. Due to the necessity of collecting sufficient amounts of samples for detailed chemical analyses, sampling time was of the order of $\sim 50 \mathrm{~h}$ for each sample. A total of eight $\mathrm{PM}_{1}$ samples were collected during the cruise (Fig. 1). The samples were stored at $-20^{\circ} \mathrm{C}$ until extraction and NMR analysis.

For high-performance liquid chromatography mass spectrometry (HPLC-MS) analyses, aerosol samples were collected on PTFE fiber filters $(70 \mathrm{~mm}$ diameter, Pallflex T60A20, Pall Life Science) with flow rates of 2.31$2.41 \mathrm{~m}^{3} \mathrm{~h}^{-1}$ through a $\mathrm{PM}_{2.5}$ inlet. Sampling times ranged from 12 to $24 \mathrm{~h}$, resulting sampling volumes of $28.1-56.1 \mathrm{~m}^{3}$ of air. As outlined above, sampling was only allowed when the sampler was upwind the ship exhaust.

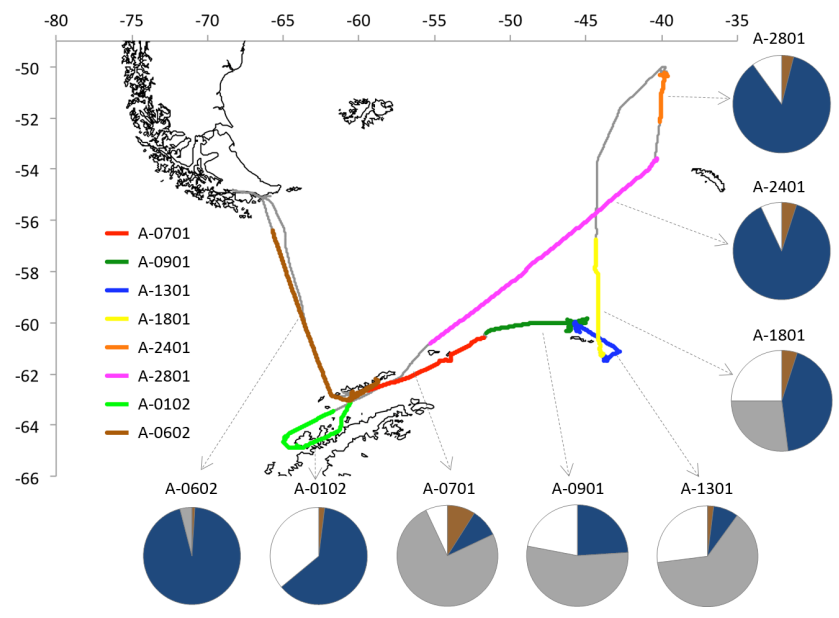

Figure 1. Cruise of RV Hesperides. The colors indicate the duration of the single aerosol samplings (short interruptions undertaken to avoid contamination from ship emissions are not indicated in the figure). The average time spent by air masses traveling over land (brown), marginal ice zone (1\%-99\% surface coverage; grey), compact sea-ice (100\% coverage; white), and open ocean (dark blue) is indicated for each sample.

\subsection{Seawater sampling and tank experiments}

Seawater samples were collected from a depth of $4 \mathrm{~m}$ using either the uppermost Niskin bottle of the CTD rosette casts or the ship's flow-through underway pumping system. The samples were filtered with a Millipore filtration apparatus on quartz-fiber filters (Whatman, $\varnothing=47 \mathrm{~mm}$ ) after a previous cut off at $10 \mu \mathrm{m}$ performed with a polycarbonate filter (Millipore, Isopore, porosity $=10 \mu \mathrm{m}, \varnothing=47 \mathrm{~mm}$ ). In total 45 samples were collected for subsequent quantification of the particulate organic carbon (POC) and $20 \mathrm{~mL}$ of the filtrates were stored for subsequent analysis of dissolved organic carbon (DOC). All the samples were stored at $-20^{\circ} \mathrm{C}$ until the chemical analyses. Three samples of sea ice from the marginal ice zone in the northern Weddell Sea were also collected using the methodology described in Dall'Osto et al. (2017). The samples, once melted, were filtered and treated similarly to the seawater samples.

Seawater was pumped from a depth of $4 \mathrm{~m}$ to fill an airtight high-grade stainless steel tank $(200 \mathrm{~L})$ designed for aerosol generation experiments. Sea-ice samples were also introduced and melted in the tank for dedicated experiments. Water was dropped from the top of the tank as a plunging jet at a flow rate of $20 \mathrm{~L} \mathrm{~min}^{-1}$. The entrained air formed bubbles that, upon bursting, produced sea-spray aerosol, as reported in O'Dowd et al. (2015). Particle-free compressed air was blown into the tank headspace $\left(120 \mathrm{~L} \mathrm{~min}^{-1}\right)$, which had outlet ports leading to samplers for the collection of filters and the subsequent offline chemical characterization of the produced sea spray. In particular, nine sea-spray aerosol samples were collected for approximately $72 \mathrm{~h}$ by a $\mathrm{PM}_{1}$ 
sampler (flow rate $40 \mathrm{~L} \mathrm{~min}^{-1}$ ) equipped with pre-washed and pre-baked quartz-fiber filters (PALL, $\varnothing=47 \mathrm{~mm}$ ). In six cases, bubble-bursting experiments were conducted in the tank continuously flushed with fresh seawater conveyed form the ship's pumping system. In the three sea-ice experiments, bubble bursting was carried out in a closed-loop system instead because of the limited amount of water volume available from the melted sea-ice samples. In this case, the bubble-bursting process could lead to chemical and biological modifications in the samples like a progressive depletion of surfactants on the film. Quantification of such artifacts is unavailable. Nevertheless, past studies carried out in different geographical region of the northeast Atlantic but with the same apparatus showed no evidence of decreasing organic enrichment in the generated sea spray when operated in a closed-loop system (O'Dowd et al., 2015).

Parallel bubble-bursting aerosol generation experiments with the same seawater and sea-ice samples were carried out using a smaller glass tank (10 L) continuously flushed with particle-free air (11 L min ${ }^{-1}$; Schwier et al., 2015) and were dedicated to sea-spray aerosol characterization using online mass spectrometers (HR-ToF-AMS and ATOFMS). The results from the bubble-bursting experiments in the small tank are already reported in Dall'Osto et al. (2017).

\section{$2.3 \quad{ }^{1}$ H-NMR spectroscopy}

Quartz-fiber filters from both ambient POC filter samples and sea-spray generation experiments were extracted with deionized ultrapure water (Milli-Q) in a mechanical shaker for $1 \mathrm{~h}$ and the water extract was filtered on PTFE membranes (pore size: $0.45 \mu \mathrm{m}$ ) in order to remove suspended particles. The water-soluble organic carbon (WSOC) content was quantified using a TOC-TN thermal combustion analyzer (Multi N/C 2100 by Analytik Jena; Rinaldi et al., 2007). Aliquots of the aerosol extract were dried under vacuum and re-dissolved in deuterium oxide $\left(\mathrm{D}_{2} \mathrm{O}\right)$ for organic functional group characterization by ${ }^{1} \mathrm{H}$-NMR spectroscopy, as described in Decesari et al. (2000). The ${ }^{1} \mathrm{H}-\mathrm{NMR}$ spectra were acquired at $600 \mathrm{MHz}$ in a $5 \mathrm{~mm}$ probe using a Varian Unity INOVA spectrometer, at the NMR facility of the Department of Industrial Chemistry (University of Bologna). Sodium 3-trimethylsilyl$\left(2,2,3,3-\mathrm{d}_{4}\right)$ propionate $\left(\mathrm{TSP}-\mathrm{d}_{4}\right)$ was used as an internal standard by adding $50 \mu \mathrm{L}$ of a $0.05 \% \mathrm{TSP}^{-\mathrm{d}_{4}}$ (by weight) in $\mathrm{D}_{2} \mathrm{O}$ to the standard in the probe. To avoid the shifting of $\mathrm{pH}$-sensitive signals, the extracts were buffered to $\mathrm{pH} \sim 3$ using a deuterated-formate/formic-acid $\left(\mathrm{DCOO}^{-} / \mathrm{HCOOH}\right)$ buffer prior to the analysis. The speciation of hydrogen atoms bound to carbon atoms can be provided by ${ }^{1} \mathrm{H}-\mathrm{NMR}$ spectroscopy in protic solvents. On the basis of the range of frequency shifts, the signals can be attributed to $\mathrm{H}-\mathrm{C}$ containing specific functionalities (Decesari et al., 2000, 2007). A total of eight HiVol $\mathrm{PM}_{1}$ ambient aerosol samples (plus one blank), four POC samples from seawater, two POC samples from melted sea ice, three samples from the tank experiments (from aerosolization of one seawater sample and two melted sea-ice samples) plus one blank for the $47 \mathrm{~mm}$ filters were characterized by NMR spectroscopy.

\subsection{UHPLC-HESI-Orbitrap-MS}

One-half of each filter sample was extracted according to the following protocol: sonication repeated three times in 1.5, 1 , and $1 \mathrm{~mL} \mathrm{ACN/H2O}(9: 1, v / v)$ for $30 \mathrm{~min}$. The extracts were filtered through PTFE membranes (pore size: $0.45 \mu \mathrm{m}$ ), combined, dried at $50{ }^{\circ} \mathrm{C}$ under a gentle stream of $\mathrm{N}_{2}$, resuspended in $200 \mu \mathrm{L} \mathrm{ACN/H2O}(1: 4, v / v)$, and stored at $-20^{\circ} \mathrm{C}$ until analysis. Samples were analyzed in triplicate by UHPLC-HESI-HRMS using an Orbitrap mass analyzer (Q-Exactive hybrid quadrupole Orbitrap mass spectrometer, Thermo Scientific, Germany) equipped with an UHPLCSystem (Dionex UltiMate 3000 UHPLC system, Thermo Scientific, Germany) and a Hypersil Gold, C18, $50 \times 2.0 \mathrm{~mm}$ column with $1.9 \mu \mathrm{m}$ particle size (Thermo Scientific, Germany). The injection volume was $20 \mu \mathrm{L}$ and the eluents were ultrapure water with $2 \%$ acetonitrile and $0.04 \%$ formic acid (eluent A), and acetonitrile with $2 \%$ water (eluent B). The gradient of the mobile phase with a flow rate of $0.5 \mathrm{~mL} \mathrm{~min}^{-1}$ was as follows: starting with $2 \% \mathrm{~B}$ isocratic for $1 \mathrm{~min}$, increasing to $20 \% \mathrm{~B}$ in $0.5 \mathrm{~min}$, isocratic for $2 \mathrm{~min}$, increasing to $90 \% \mathrm{~B}$ in $2.5 \mathrm{~min}$, isocratic for $4 \mathrm{~min}$, and decreasing to $2 \% \mathrm{~B}$ in $0.5 \mathrm{~min}$. Mass spectrometric analyses were performed using an electrospray ionization (ESI) source under the following conditions: $30^{\circ} \mathrm{C}$ ESI temperature, $4 \mathrm{kV}$ spray voltage, 40 psi sheath gas flow, 20 psi auxiliary gas flow, and $350^{\circ} \mathrm{C}$ capillary temperature. Mass resolution was 70000 and the acquired mass range was $m / z$ 80-550. Creatinine calibration results are shown in Table S2 of the Supplement.

\subsection{Air mass back-trajectories}

Five-day back-trajectories arriving at the ship's position at 03:00, 09:00, 16:00, and 21:00 GMT every day were calculated using the HYSPLIT model (Draxler and Rolph, 2010) with GDAS data. In total, 140 air mass back-trajectories were obtained. A polar stereographic map was used to classify $24 \times 24 \mathrm{~km}$ grid cells as land, sea, and ice. From this information we calculated the percentage of time spent by each trajectory over each surface type, and particularly over sea ice. Daily maps of sea-ice percentage concentration measured on a $12.5 \mathrm{~km}$ grid were used for this calculation. Sea-ice abundance was derived from satellite microwave data (Ezraty et al., 2007) available at IFREMER. This analysis allowed also assigning air mass trajectories (and percentages of surface type flown over) to the aerosol samples collected on the filters (Fig. 1). 


\section{Results}

\subsection{Organic composition of seawater: POC samples}

The composition of seawater in terms of pigments, metabolites, fluorescent organic matter, and other organic constituents from the PEGASO cruise has been characterized in great detail (Dall'Osto et al., 2017; Nunes et al., 2019; Zamanillo et al., 2019). Marine organic substances are found in the ocean in dissolved and particulate form. Particulate organic carbon (POC) is defined operationally by a filtration cutoff at $0.45 \mu \mathrm{m}$, and recovers phytoplankton cells, bacteria, and large colloids, such as transparent exopolymeric particles ("TEPs"; Passow et al., 2002). Dissolved organic carbon (DOC) is mostly contributed by the excreta and metabolites of the marine biota but it also accounts for a pool of refractory compounds, resistant to microbial degradation, and is well mixed in the water column (Hertkorn et al., 2013). Past studies have extensively characterized the NMR features of labile and refractory organic constituents of marine organic matter (Repeta, 2015). However, the NMR characterization of the dissolved organic substances was limited to desalted fractions of DOC isolated by solid-phase extraction or ultrafiltration (Koprivnjak et al., 2009). Therefore, the NMR analysis of low molecular weight polar organic constituents of marine DOC remains elusive. In our study, we screened the NMR features of POC in phytoplankton bloom areas. In addition, samples of aerosolized seawater and melted sea ice were used as a proxy of primary marine aerosol (Dall'Osto et al., 2017). During the process of bubble-bursting performed in the tank experiments, aerosol particles became depleted in sea salt with respect to seawater and enriched in surfaceactive DOC components and in buoyant POC substances. The chemical characterization of the smallest POC component $(0.45-10 \mu \mathrm{m})$ aims to provide information about the composition of the buoyant particles, while the contribution from DOC to the surface film composition could not be determined in this study.

Figure 2 shows the proton NMR spectra of three POC samples, one from seawater (POC W3101) and two from melted sea ice (POC SeaIce-1, and POC SeaIce-3) as examples. It is worth noting that the samples were pre-filtered through a polycarbonate membrane of $10 \mu \mathrm{m}$ porosity, hence the analyzed POC fraction represents only the fine fraction (between $\sim 0.45$ and $10 \mu \mathrm{m}$ ). During PEGASO, the concentration of fine POC fraction $(0.45-10 \mu \mathrm{m})$ ranged between 8 and $12 \mu \mathrm{molC} \mathrm{L}^{-1}$ in bloom areas. The subset of samples analyzed by ${ }^{1} \mathrm{H}-\mathrm{NMR}$ spectroscopy exhibited a concentration of $10.6 \pm 0.7 \mu \mathrm{molC} \mathrm{L}^{-1}(n=4)$. Sample POC W3101 originated from the bloom area west of South Georgia Island, while the two sea-ice samples were collected in the marginal ice zone of the Weddell Sea. The interpretation of the spectra was carried out by comparison with the datasets and spectra provided by the literature on metabolomics (e.g., Bertram et al., 2009; Matulova et al., 2014; Li et al., 2015; Upad- hyay et al., 2016) as well as by means of NMR analysis of commercial standard compounds. Characteristic patterns of NMR resonances for specific compounds (e.g., patterns in multiplicity) enabled an accurate identification, while only a tentative attribution of the most simple NMR resonances (singlets) was attempted when standards were not available, because deviations with respect to published NMR data are possible when different experimental conditions (e.g., in respect to $\mathrm{pH}$ of the sample) are used. Nevertheless, the POC extracts show several NMR features overlapping with typical ones for other biological matrices. In particular, the occurrence of most common aliphatic amino acids was observed in all three samples analyzed and particularly in sample POC SeaIce-1. Acidic amino acids dominated over the basic ones, while aromatic residuals were detected only in trace amounts (Fig. S1). The identification of modified amino acids among the most typical natural products of the Antarctic microbiota, such as mycosporines (Oyamada et al., 2007), could not be carried out in detail because of the lack of suitable spectral libraries. The presence of metabolites such as low molecular weight nitrogen-containing compounds (choline, betaine, etc.) is confirmed by the singlets in the chemical shift range 3.1-3.3 ppm from methyls bound to nitrogen atoms $\left(\mathrm{H}_{3} \mathrm{C}-\mathrm{N}\right.$ ). Resonances at higher chemical shift ranges, between 3.4 and 4.2, recovered the -NCHRCO- groups of alpha-amino acids and the H-C-O groups of sugars and polyols: traces of glycerol were found in all three samples analyzed, while glucose was found in trace amounts in samples POC W3101 and as a major component in sample POC SeaIce-3 (Fig. S2). These results confirm the potential of ${ }^{1} \mathrm{H}-\mathrm{NMR}$ spectroscopy for the characterization of marine metabolites and natural products. The small set of POC samples analyzed in this study is, however, mainly aimed at providing spectral fingerprints useful for the interpretation of the results of the aerosol sample analyses discussed in the following sections.

\subsection{Organic composition of bubble-bursting aerosols}

The three primary marine aerosol samples collected in the tank and analyzed by ${ }^{1} \mathrm{H}$-NMR spectroscopy included the following samples. One sample was collected from bubble bursting of seawater (BB W1101) obtained during almost $4 \mathrm{~d}$ of navigation west and north of the South Orkney Islands. Seawater was continuously flushed onboard RV Hesperides maintaining continuous sea-spray production in the tank. The other two samples (BB SeaIce-1 and BB SeaIce-3) were obtained from two of the three sea-ice samples melted in the tank and run in a closed-loop system. Sea ice was collected from the marginal ice zone around $100 \mathrm{~km}$ south of the South Orkney Islands by using small inflatable boats and clean laboratory ware. The chemical information obtained for these bubble-bursting aerosols is, therefore, representative for primary marine particles in the northern sector of the Weddell Sea. The natural process of sea spray - mimicked by the experiments carried out in the tank onboard RV Hesperides - 


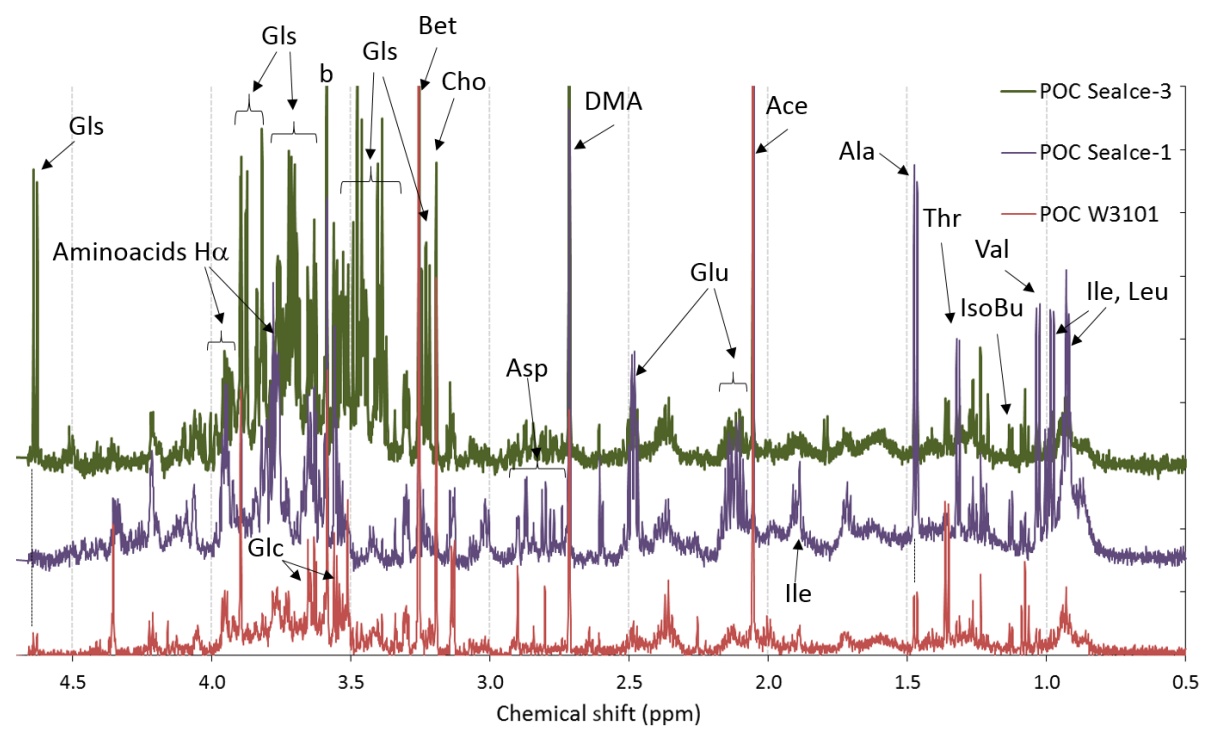

Figure 2. Aliphatic region of the ${ }^{1}$ H-NMR spectra of three POC sample extracts: one for the seawater sample (POC W3201) and two from melted sea ice (POC SeaIce-1 and POC SeaIce-3). Specific NMR resonances were assigned to the following: the residuals of amino acids (Ala, Thr, Val, Ile, Leu, Glu and Asp) and their alpha hydrogen atoms, isobutyric acid (IsoBu), acetic acid (Ace), dimethylamine (DMA), N-osmolytes (Bet: betaine; Cho: choline), glycerol (Glc), and glucose (Gls).

selectively transfers organic compounds from seawater into the aerosol depending on the ability of the specific pools of organic substances to enrich in the surface microlayer and/or to be scavenged by rising air bubbles. The selective nature of such process is witnessed by our NMR data, showing that the seawater composition dominated by amino acids, osmolytes, and sugars/polyols differs quite substantially from that of bubble-bursting aerosols from the tank experiments (Fig. 3, Fig. S3). Bubble-bursting aerosol was characterized by the occurrence of low molecular weight metabolites like lactic acid and amines (dimethylamine, DMA, and traces of monomethylamines and trimethylamines), which likely originated from DOC components of seawater. The most characteristic feature of the spectra is, however, the bands at 0.9 and $1.3 \mathrm{ppm}$ of chemical shift. These correspond to aliphatic chains with terminal methyl moieties typical of lipids. Their occurrence in the aerosolized seawater and not in the POC samples can be explained by an enrichment of surface-active compounds from DOC in the surface microlayer. Lipid enrichment in aerosol from bubble-bursting experiments has already been documented by the two previous studies reporting NMR composition data (Facchini et al., 2008; SchmittKopplin et al., 2012). Nevertheless, our findings clearly show that, beside lipids, there are specific constituents of POC taking part in the formation of primary aerosol particles in the tank experiments. In particular, the spectral region for sugars and polyols in bubble-bursting aerosols is completely consistent with the spectral features of POC (Fig. S4), although the contribution of the -NCHRCO- groups of amino acids in the same spectral window is clearly missing in the aerosol. The presence of nitrogen-containing metabolites (betaine) is confirmed in the aerosol samples from the tank. It is plausible that betaine, glycerol, and other sugars have a chemical bond to lipids, making glycolipids and phospholipids, which could explain their preferential enrichment during the aerosolization process with respect to other POC constituents like amino acids. It is a matter of fact that amino acids could be detected only in very trace amounts (the doublet of alanine at $1.45 \mathrm{ppm}$ is barely visible) in the sea-spray samples. Other molecular tracers found in previous sea-spray experiments in other geographical regions, such as acrylic acid (SchmittKopplin et al., 2012), which is also product of DMSP degradation, were not found in our experiment.

\subsection{Organic composition of ambient submicron WSOC samples}

The eight ambient $\mathrm{PM}_{1}$ HiVol samples analyzed for organic composition include six that were collected in parallel to the impactor samples discussed in Dall'Osto et al. (2017). The proton NMR spectra of the eight samples are reported in Figs. S5-S7. Air mass origin varied largely during the cruise, with transport from the Weddell Sea prevalent during the first half of the cruise turning into open-ocean prevailing air masses during the second half (Fig. 1). Two samples (A-0701 and A-0102) of mixed origin were omitted by Dall'Osto et al. (2017), who focused on the comparison between aerosols from the sympagic regions and those from the open ocean. We applied hierarchical cluster analysis to investigate if a dual classification also held with the NMR spectra (Fig. 4). The original spectra were normalized to their integrals and binned to 354 points before clustering. Two 


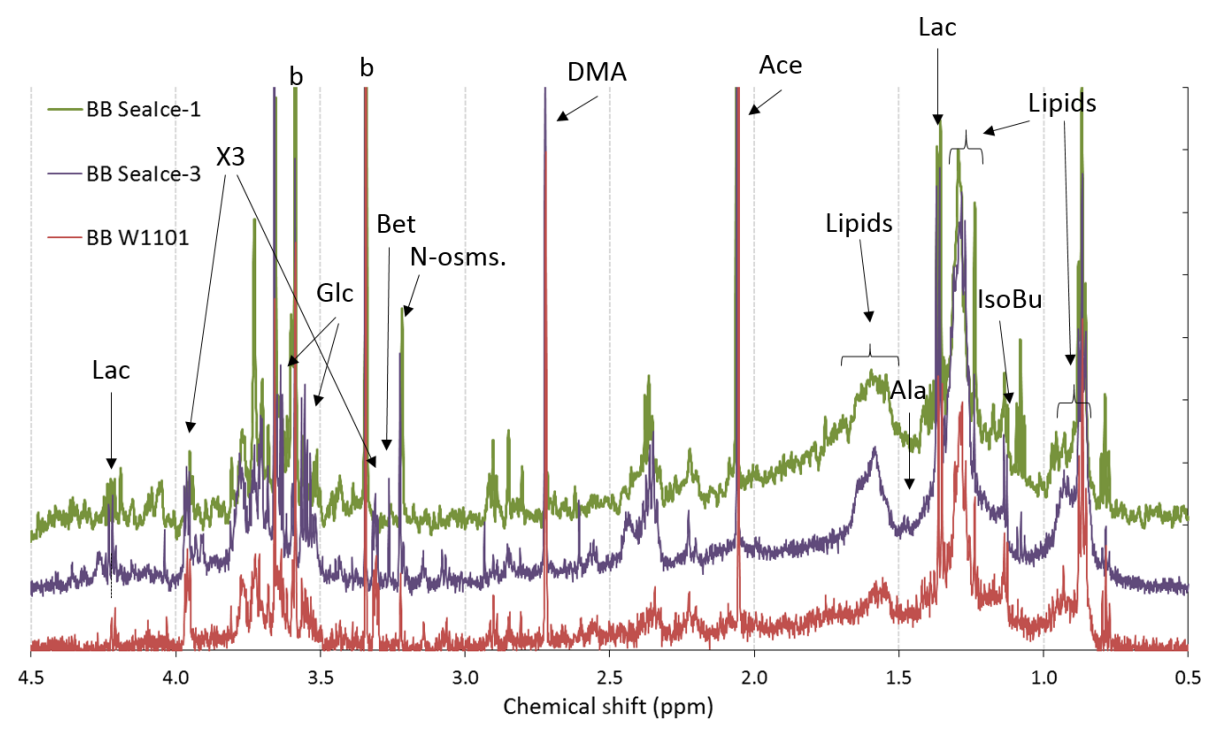

Figure 3. The same as Fig. 2 but for the three bubble-bursting aerosols: from seawater sample W1101 (BB W1101) and melted sea ice no. 1 and no. 3 (BB SeaIce-1 and BB SeaIce-3). Specific resonances were assigned to lactic acid (Lac), acetic acid (Ace), isobutyric acid (IsoBu), alanine (Ala), dimethylamine (DMA), glycerol (Glc), N-osmolytes (Bet: betaine; "N-osms": unidentified, possibly phosphocholine), and blank contaminations (b). Unresolved mixtures of aliphatic compounds were identified as lipids.

main clusters were indeed identified: a first one recovering three samples collected downwind the Weddell Sea during the first half of the cruise, and a second cluster with samples representative of a greater diversity of conditions, from the Drake Channel to the Antarctic Peninsula and the productive waters around South Georgia Island. This second cluster corresponds to the samples characteristic for the open-ocean conditions in Dall'Osto et al. (2017) plus samples A-0701 and A-0102. Unexpectedly, sample A-0701, whose air mass spent most of time over sympagic waters (Fig. 1) clustered together with the samples from the open ocean according to NMR composition. It is noticeable, however, that binned NMR spectra can only trace the distribution of the major organic functional groups while the information carried by fine spectral features, which is critical to detect the presence of specific molecular markers, is not taken into account in the cluster analysis. In the following sections, we will show that sample A-0701 exhibits a peculiar NMR composition which must be put in relation to terrestrial sources of organic compounds. On the basis of the back-trajectories (Figs. 1 and 8), the likely land sources were located in the Antarctic Peninsula. In summary, the variability in the distribution of NMR functional groups in ambient $\mathrm{PM}_{1}$ samples (Table 1) was primarily driven by the air mass origin over sympagic (Weddell Sea) or pelagic waters, in agreement with the results on inorganic compounds, WSOC, and amines reported by Dall'Osto et al. (2017, 2019). Nevertheless, the analysis of fine NMR spectral features supports the existence of a third source area over land. In the following discussion, we will provide an indepth description of the NMR compositions for these three source sectors.

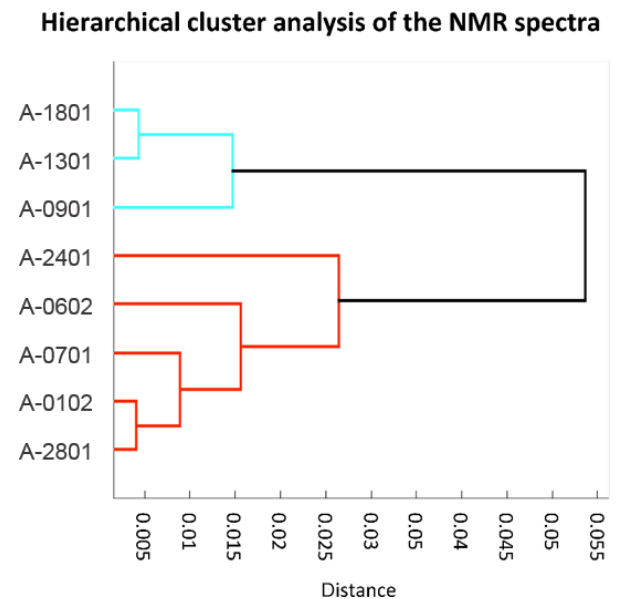

Figure 4. Cluster analysis of the ${ }^{1} \mathrm{H}-\mathrm{NMR}$ spectra of the $\mathrm{PM}_{1} \mathrm{HiVol}$ samples of ambient aerosol. Units for correlation distance are dimensionless.

\subsubsection{Ambient aerosols from the Weddell Sea}

Sample A-0901 was collected in the marginal ice zone of the Weddell Sea. Its spectrum shows a complete absence of aromatic compounds and alkenes (Fig. S7). The aliphatic region (Figs. 5, S8) exhibits broad similarity to that of the primary marine particles generated in the sea-spray tank, but with a major difference in the chemical shift range between 1.7 and $3.0 \mathrm{ppm}$ where the background broad NMR bands are much more intense in the ambient sample. This is also the region recovering the signals from acyl groups $(\mathrm{RCH}-$ $(\mathrm{C}=\mathrm{O})-)$ in aliphatic carboxylic acids and keto acids, which 
Table 1. Concentrations of ${ }^{1} \mathrm{H}-\mathrm{NMR}$ functional groups and of molecular markers determined in the ambient aerosol samples. ND: not detected. NA: not available because of the interference of organic compounds with overlapping chemical shifts.

\begin{tabular}{|c|c|c|c|c|c|c|c|c|}
\hline $\begin{array}{l}\text { Sample ID } \\
\text { Sampling times }\end{array}$ & $\begin{array}{r}\text { A-0701 } \\
7 \text { Jan 20:00- } \\
\text { 9 Jan 09:00 }\end{array}$ & $\begin{array}{r}\text { A-0901 } \\
\text { 9 Jan 14:50- } \\
\text { 13 Jan 13:50 }\end{array}$ & $\begin{array}{r}\text { A-1301 } \\
\text { 13 Jan 19:20- } \\
\text { 18 Jan 12:20 }\end{array}$ & $\begin{array}{r}\text { A-1801 } \\
\text { 18 Jan 13:30- } \\
\text { 21 Jan 23:55 }\end{array}$ & $\begin{array}{r}\text { A-2401 } \\
\text { 24 Jan 15:00- } \\
\text { 28 Jan 05:15 }\end{array}$ & $\begin{array}{r}\text { A-2801 } \\
\text { 28 Jan 13:30- } \\
\text { 31 Jan 13:50 }\end{array}$ & $\begin{array}{r}\text { A-0102 } \\
\text { 1 Feb 14:50- } \\
6 \text { Feb 03:15 }\end{array}$ & $\begin{array}{r}\text { A-0602 } \\
6 \text { Feb 22:00- } \\
10 \text { Feb 11:00 }\end{array}$ \\
\hline \multicolumn{9}{|c|}{ Average air mass type } \\
\hline & $\begin{array}{l}\text { Weddell Sea/ } \\
\text { ctic Peninsula }\end{array}$ & $\begin{array}{r}\text { Weddell } \\
\text { Sea }\end{array}$ & $\begin{array}{r}\text { Weddell } \\
\text { Sea }\end{array}$ & $\begin{array}{r}\text { Weddell } \\
\text { Sea }\end{array}$ & $\begin{array}{l}\text { Open } \\
\text { ocean }\end{array}$ & $\begin{array}{l}\text { Open } \\
\text { ocean }\end{array}$ & $\begin{array}{r}\text { Open ocean/ } \\
\text { mixed }\end{array}$ & $\begin{array}{l}\text { Open } \\
\text { ocean }\end{array}$ \\
\hline \multicolumn{9}{|c|}{ Water-soluble organic carbon $\left(\mu \mathrm{gC} \mathrm{m}^{-3}\right)$} \\
\hline WSOC & 0.14 & 0.07 & 0.12 & 0.13 & 0.09 & 0.14 & 0.05 & 0.11 \\
\hline \multicolumn{9}{|c|}{${ }^{1} \mathrm{H}-\mathrm{NMR}$ functional groups $\left(\mathrm{nmolH}^{-3}\right)$} \\
\hline $\mathrm{H}-\mathrm{C}$ & 2.60 & 2.16 & 2.28 & 3.03 & 3.27 & 2.81 & 2.07 & 2.82 \\
\hline $\mathrm{H}-\mathrm{C}-\mathrm{C}=\mathrm{O}$ & 2.40 & 1.58 & 1.80 & 2.10 & 1.91 & 1.86 & 1.28 & 1.78 \\
\hline $\mathrm{H}-\mathrm{C}-\mathrm{O}$ & 2.15 & 0.57 & 0.69 & 0.83 & 2.06 & 0.99 & 0.99 & 1.41 \\
\hline $\mathrm{O}-\mathrm{CH}-\mathrm{O}$ & 0.20 & 0.07 & 0.05 & 0.04 & 0.08 & 0.09 & 0.07 & 0.09 \\
\hline Ar-H & 0.12 & 0.05 & 0.00 & 0.10 & 0.09 & 0.10 & 0.11 & 0.07 \\
\hline MSA & 2.13 & 1.95 & 2.63 & 4.54 & 1.72 & 2.90 & 2.22 & 1.53 \\
\hline Alkylamines & 0.30 & 0.79 & 0.53 & 1.32 & 0.34 & 0.49 & 0.13 & 0.15 \\
\hline \multicolumn{9}{|c|}{ Molecular markers $\left(\mathrm{ng} \mathrm{m}^{-3}\right)$} \\
\hline MSA & 68 & 62 & 84 & 145 & 55 & 93 & 71 & 49 \\
\hline methylamines & 2.31 & 5.5 & 3.79 & 9.0 & 2.53 & 3.56 & 0.92 & 1.20 \\
\hline creatinine & 0.09 & 1.65 & 1.52 & 2.21 & $\sim 0.05$ & 1.00 & 0.29 & 0.41 \\
\hline glycerol & NA & 1.1 & 0.7 & 0.7 & 3.0 & 0.8 & 0.7 & 1.3 \\
\hline sucrose & 11 & ND & ND & ND & ND & ND & ND & ND \\
\hline alanine & ND & ND & $\operatorname{traces}^{1}$ & traces $^{1}$ & 0.6 & ND & ND & 0.7 \\
\hline betaine & ND & ND & ND & ND & $\operatorname{traces}^{2}$ & ND & ND & ND \\
\hline
\end{tabular}

1 below the limit of quantification $\left(0.3 \mathrm{ng} \mathrm{m}^{-3}\right)$.

2 below the limit of quantification $\left(0.2 \mathrm{ng} \mathrm{m}^{-3}\right)$.

are formed by volatile organic compound (VOC) oxidation in the atmosphere (Barbaro et al., 2017). The most abundant individual compounds detected in these samples were, however, MSA (Fossum et al., 2018) and the low molecular methylamines (MMA, DMA, TMA). The predominance of semivolatile $\mathrm{C}_{1}-\mathrm{C}_{3}$ alkylamines (Ge et al., 2011) indicates that the amines form in the ambient aerosol by secondary processes involving volatilization from the ocean surface and recondensation onto acidic aerosol particles (Dall'Osto et al., 2019). The aliphatic bands at 0.9 and $1.3 \mathrm{ppm}$ in sample A-0901 show a partial overlap with the resonances of the lipids in the aerosolized seawater. However, the bands at $1.6 \mathrm{ppm}$ and $2.2-2.3 \mathrm{ppm}$ which, in lipids, correspond to methylenes in beta and alpha position to a $\mathrm{C}=\mathrm{O}$ group, are much more intense in the spectrum of A-0901 than in BB SeaIce-3 (Fig. S8), indicating that aliphatic chains are shorter and more substituted in the ambient aerosol than in nascent primary aerosol particles. The pattern of bands at $0.9,1.3$, $1.6,2.2,2.4$, and $2.6 \mathrm{ppm}$ follows the structure elucidated by Suzuki et al. (2001) and is attributed to $\mathrm{C}_{7}-\mathrm{C}_{9}$ aliphatic dicarboxylic acids and oxo- acids. This class of organic compounds, clearly characterizing the aliphatic composition of the ambient samples in the Weddell Sea area, could originate from degraded (oxidized) lipids (Kawamura et al., 1996), or from gas-to-particle conversion of carbonyls produced by the photochemical oxidation of lipids at the air-sea interface (Bernard et al., 2016; Alpert et al., 2017). Support for the lat- ter hypothesis (secondary formation) is given by the fact that the N-osmolytes (betaine, choline) present in the sea spray generated in the tanks were completely absent in the ambient sample. Nevertheless, the resonances in the spectral window 3.5-3.8 ppm in sample A-0901 are completely consistent with the occurrence of glycerol, indicating that in fact primary aerosol particles contributed to the composition of the ambient aerosol in this region (Fig. S9). There is another striking difference between the composition of the ambient aerosol and sea-spray particles: the former contains significant levels $\left(1.65 \mathrm{ng} \mathrm{m}^{-3}\right)$ of creatinine. This compound is responsible for the two singlets at 3.12 and $4.27 \mathrm{ppm}$ of chemical shift and was identified by the comparison with a standard under identical NMR experimental conditions (Fig. S11). The concentration of creatinine clearly follows that of low molecular weight amines (Fig. 6) and shows a maximum in the three samples collecting most of the air masses that traveled over the Weddell Sea. Creatinine was also determined by HPLC/-MS analysis in a parallel set of filter samples collected onboard Hesperides during the PEGASO cruise (see Sect. 2.4). Identification was based on MS/MS fragmentation patterns and retention time. Quantification was based on chromatographic peak area. Figure 7 shows extracted ion chromatograms for $m / z$ 114.0655-114.0667, corresponding to creatinine, of the filter extract of sample $0119 \mathrm{~N}$ obtained during the PEGASO campaign and the neat creatinine standard. The HPLC/MS analysis indicates that creatinine oc- 
curred in concentrations of $20-50 \mathrm{pg} \mathrm{m}^{-3}$ in the samples from the Weddell Sea area (Table S1 in the Supplement), much less than the concentrations determined by ${ }^{1} \mathrm{H}-\mathrm{NMR}$ spectroscopy (1.6-2.5 $\mathrm{ng} \mathrm{m}^{-3}$, Table 1). Such discrepancy can be due to the different extraction protocols and to nonideal chromatographic conditions in HPLC/MS for creatinine quantification (elution close to the void volume). Nevertheless, our findings demonstrate that high-field NMR methods can integrate HPLC/MS analysis for the identification of molecular markers in atmospheric aerosol complex organic mixtures.

\subsubsection{Ambient aerosols in the open ocean}

Sample A-2401 was collected during the northern transit of the cruise, RV Hesperides just west of South Georgia Island $\left(55^{\circ} \mathrm{S}\right.$; Fig. 1). During sampling, the air masses had a westerly component and can be considered representative of Southern Ocean conditions. The ${ }^{1} \mathrm{H}-\mathrm{NMR}$ spectrum of A-2401 shares similarities with that of A-0901 described above: (a) the resonances of MSA and methylamines are much more intense than those of other low molecular weight compounds (such as $\mathrm{N}$-osmolytes); (b) the spectral region of acyls (1.8-3.0 ppm) accounting for unresolved carboxylic acids is clearly more intense than in the spectrum of primary organic aerosols; (c) the pattern of bands at 0.9, 1.3, 1.6, and 2.2-2.4 ppm highlights the presence of linear aliphatic structures substituted with oxo- and carboxylic groups. Nevertheless, MSA and the low molecular weight amines were less abundant in A-2401 than in the sample from the Weddell Sea (Table 1). Also the ratio between acyl $(\mathrm{CH}-\mathrm{C}=\mathrm{O})$ and alkyl $(\mathrm{CH}-\mathrm{CH})$ groups was smaller in A-2401 than in A-0901 (Fig. S8). The linear aliphatic structures involved longer methylenic chains in A-2401 than in A-0901, so that in the former case they were more similar to the aliphatic structures of the aerosolized melted sea ice (Fig. S8). Another difference between the two ambient aerosol samples is that the one from the Southern Ocean contains much more alcoxy groups (HC-O, in the chemical shift range 3.4-4.2 ppm) of polyols than the one from the Weddell Sea (Fig. 5; Table 1). When comparing the functional group distributions of the ambient aerosol samples to that of the aerosol generated during the tank experiments, clearly the samples from the Southern Ocean show a better match than the samples from the Weddell Sea do. Other similarities between the composition of A-2401 and the aerosol in the tank can be found in the fine structures of the spectra, especially in the ranges of aromatics, acetals, and polyols (Fig. S12). A-2401 clearly contains traces of organic markers of primary aerosols and specifically glycerol, N-osmolytes (Fig. S10), and amino acids (alanine). Finally, in contrast with A-0901, sample A2401 contains only trace amounts of creatinine.

\subsubsection{Ambient aerosols influenced by coastal land sources}

Sample A-0701 was collected in the western sector of the Weddell Sea. The air masses showed several passes over the Antarctic Peninsula. The ${ }^{1} \mathrm{H}-\mathrm{NMR}$ spectrum shows unique features: isobutyric acid was found in relatively high concentrations, together with an amine tentatively identified as cadaverine (Fig. 5). The aliphatic chains are found in much lower amounts than in the samples described above; the band of acyls is not as pronounced as in A-0901 (Fig. S8), whereas alcoxyls are abundant, especially due to the occurrence of sucrose at a remarkable concentration of $10 \mathrm{ng} \mathrm{m}^{-3}$. Finally, no creatinine was found in this sample. Clearly, the composition of A-0701 is drastically different from that of the other samples collected in the Weddell Sea. The presence of sucrose (Fig. S9) points to a contribution from primary biological particles emitted from a terrestrial biota, not a marine one. Vegetation cover (scarce but present) in the Antarctic Peninsula can be responsible for such emissions. The NMR composition of A-0701 provides evidence of the diversity of biogenic aerosol sources active in this area of the world.

\section{Discussion}

\subsection{Source apportioning of primary and secondary organic components in different regions}

The comparison of the NMR compositions of the ambient aerosol samples collected onboard RV Hesperides (Fig. 8) supports the differentiation of aerosol sources between the sympagic and pelagic environments introduced by Dall'Osto et al. (2017). The higher abundance of alkyl (C-H) and alcoxy (H-C-O) groups detected in the second half of the cruise points to a larger fraction of primary organic compounds rich in lipids and polyols in the aerosols of the open Southern Ocean. Analogous compositions were obtained using FTIR spectroscopy at Ross Island (Liu et al., 2018). In our study, the attribution of compound classes and molecular markers (such as glycerol and N-osmolytes) to primary marine particles was supported by the comparison with the analysis of tank-generated sea-spray particles. According to our NMR datasets, primary marine organics were ubiquitous in the region as witnessed by the presence of glycerol in all samples. However, glycerol accounted for almost the entire polyol content in the three samples from the eastern/northern Weddell Sea, while the samples from the open ocean contained much larger and more complex mixtures of polyols/sugars. Free amino acids (alanine) in the sub-ng $\mathrm{m}^{-3}$ range and $\mathrm{N}$ osmolytes in trace amounts with a greater abundance of linear aliphatic structures similar to lipids in the samples from the Southern Ocean point to a major contribution of primary organics to submicron organic aerosols in this environment. These findings provide further confirmation of the impor- 


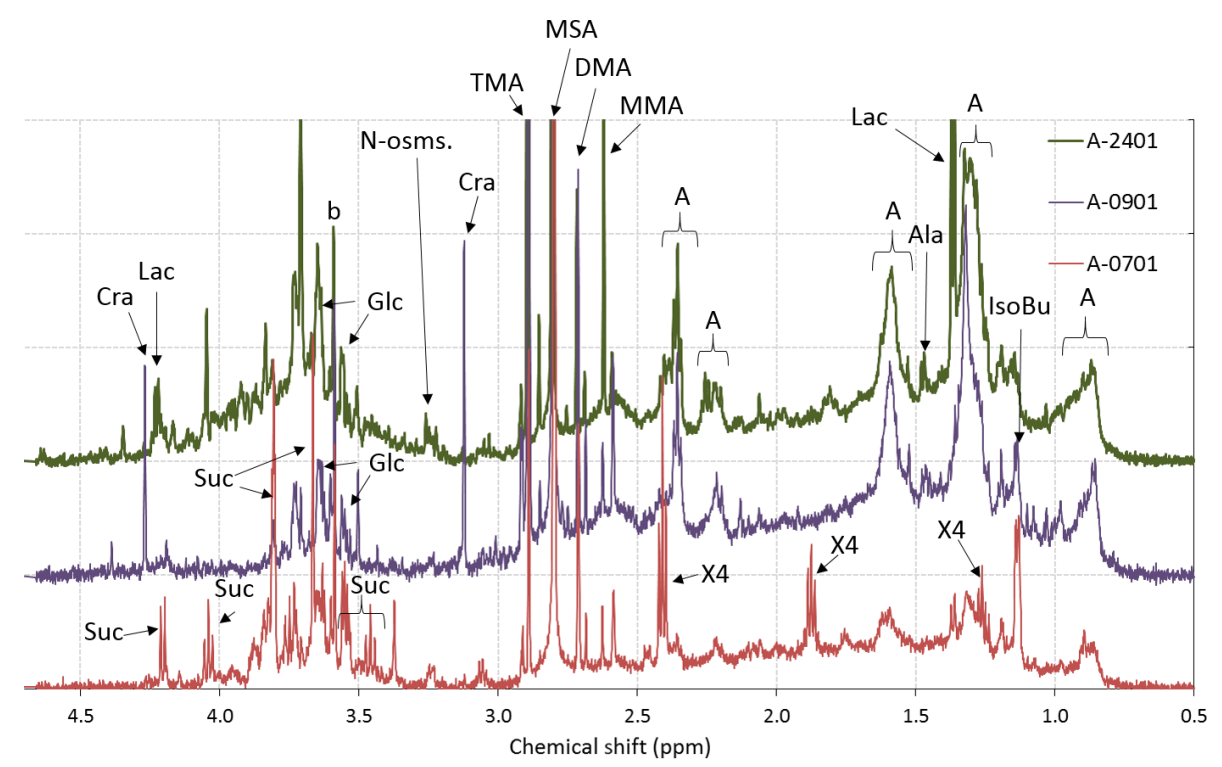

Figure 5. The same as Fig. 2 but for the three ambient submicrometer aerosol samples. Specific resonances were assigned to lactic acid (Lac), isobutyric acid (IsoBu), alanine (Ala), monomethylamine (MMA), dimethylamine (DMA), trimethylamine (TMA), glycerol (Glc), sucrose (Suc), creatinine (Cra), and blank contaminations (b). Unresolved mixtures of linear aliphatic compounds (A), including possible contributions from lipids, are indicated in the spectra. Other NMR signals were only tentatively attributed to cadaverine (X4).

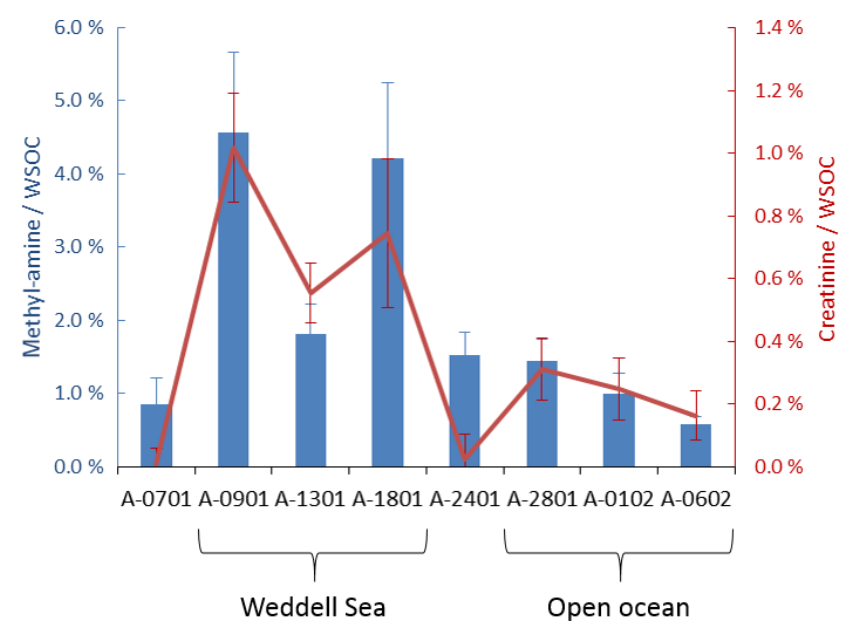

Figure 6. Concentrations of creatinine and methylamines in the $\mathrm{PM}_{1}$ samples. The concentrations are expressed as contributions to WSOC (mol \% of carbon). "Weddell Sea" and "Open ocean" labels indicate the sampling periods identified by Dall'Osto et al. (2017) to characterize the aerosol composition in air masses traveling over sea ice and in the Southern Ocean, respectively.

tance of sea spray as a source of marine organic particles in oceanic regions characterized by high productivity and strong wind stress.

In sympagic waters, other mechanisms of aerosol formation take place. Sympagic waters are rich in S- and $\mathrm{N}$ osmolytes produced by the algal communities colonizing the sea ice. The osmolytes degrade to VOCs which are then con- verted to secondary organic aerosol (SOA) components, such as MSA (Davison et al., 1996) and low molecular weight methylamines (Facchini et al., 2008). Also the distribution of the oxygenated functional groups was different between sympagic and pelagic regimes. While alcoxyl groups (H-C$\mathrm{O})$ from polyols and sugars account for almost $50 \%$ of total alcoxyl $(\mathrm{H}-\mathrm{C}-\mathrm{O})$ and acyls $(\mathrm{H}-\mathrm{C}-\mathrm{C}=\mathrm{O})$ in the samples from the Southern Ocean, the fraction is less than $30 \%$ in the three samples from the offshore areas of the Weddell Sea (Fig. 8). The mixtures of organic compounds carrying acyls, like carboxylic and oxocarboxylic acids, are not associated with primary marine aerosols and are likely components of SOA. Carboxylic acids can form photochemically (Cui et al., 2019) during the austral summer. The nature of parent VOCs regarding carboxylic acids in our samples is unknown, but the occurrence of linear aliphatic compounds containing oxo- and carboxylic groups indicates that one of the possible sources if found in the oxidative degradation of lipids - either in the aerosol or in the marine microlayer - as suggested by past studies in Antarctica (Kawamura et al., 1996) and consistent with recent AMS observations in the Arctic marginal ice zone (Willis et al., 2017).

In the Weddell Sea, under the influence of air masses that had traveled over the Peninsula (sample A-0701), the contribution of the emissions from the land biota became evident, therefore supporting the observations of Schmale et al. (2013) on the contribution of primary biological particles from the coastal land ecosystems. Our data suggest that beside animal colonies, the land vegetation (grasses, mosses, lichens) of the Antarctic Peninsula can also contribute to the 

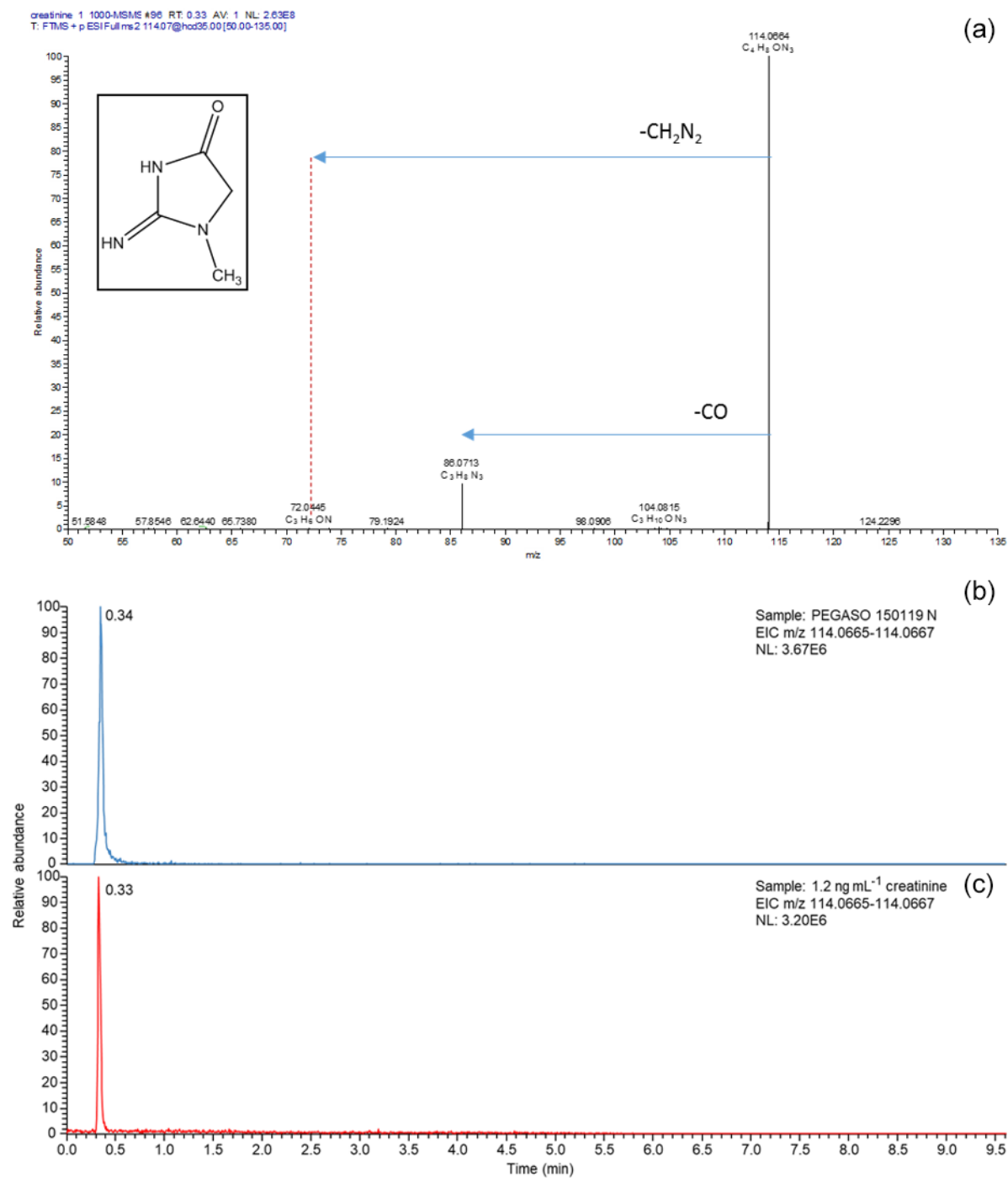

(b)

Figure 7. (a) MS spectrum of a creatinine standard. (b) Extracted ion chromatograms for $m / z$ 114.0655-114.0667, corresponding to creatinine, of the filter extract of sample $0119 n$ obtained during the PEGASO campaign and the neat creatinine standard. The retention time of creatinine was found to be 0.33 min using the conditions outlined in Sect. 2.4.

emission of particles, and in particular to the content of sugars. Other biological compounds of primary origin, the amino acids, were not found in the Weddell Sea in our study. These results contrast with the previous findings that a significant fraction of the ambient $\mathrm{PM}_{1}$ mass was accounted for by proteinaceous material at an island site in the Southern Ocean (Schmale et al., 2013). On the other hand, the observations of Schmale et al. (2013) were carried out under the direct influence of the emissions of seabird colonies, while our observations were carried out offshore. More research is needed to quantify the range and extent to which primary particles from the terrestrial biota impact the marine aerosol composition in the Antarctic region.

\subsection{A new potential marker: creatinine}

The source of creatinine in ambient aerosol is controversial. On the basis of its chemical structure, it is water soluble but clearly less volatile than the methylamines and, as a consequence, its Henry coefficient must be much less favorable for transferring this amine out of seawater into the gas phase. A primary origin via sea spray is also doubtful because creatinine is not a strong surfactant. On the other hand, Prather et al. (2013) showed that sea-spray aerosols encompass several classes of organic particles, including some made of biological material: POC particles and large colloids can be scavenged by rising bubbles and injected in the atmosphere by jet drops. Jet drop emission represents a plausible mechanism to transfer primary organic compounds which are not strong surfactants from seawater to the atmosphere. If this happened 

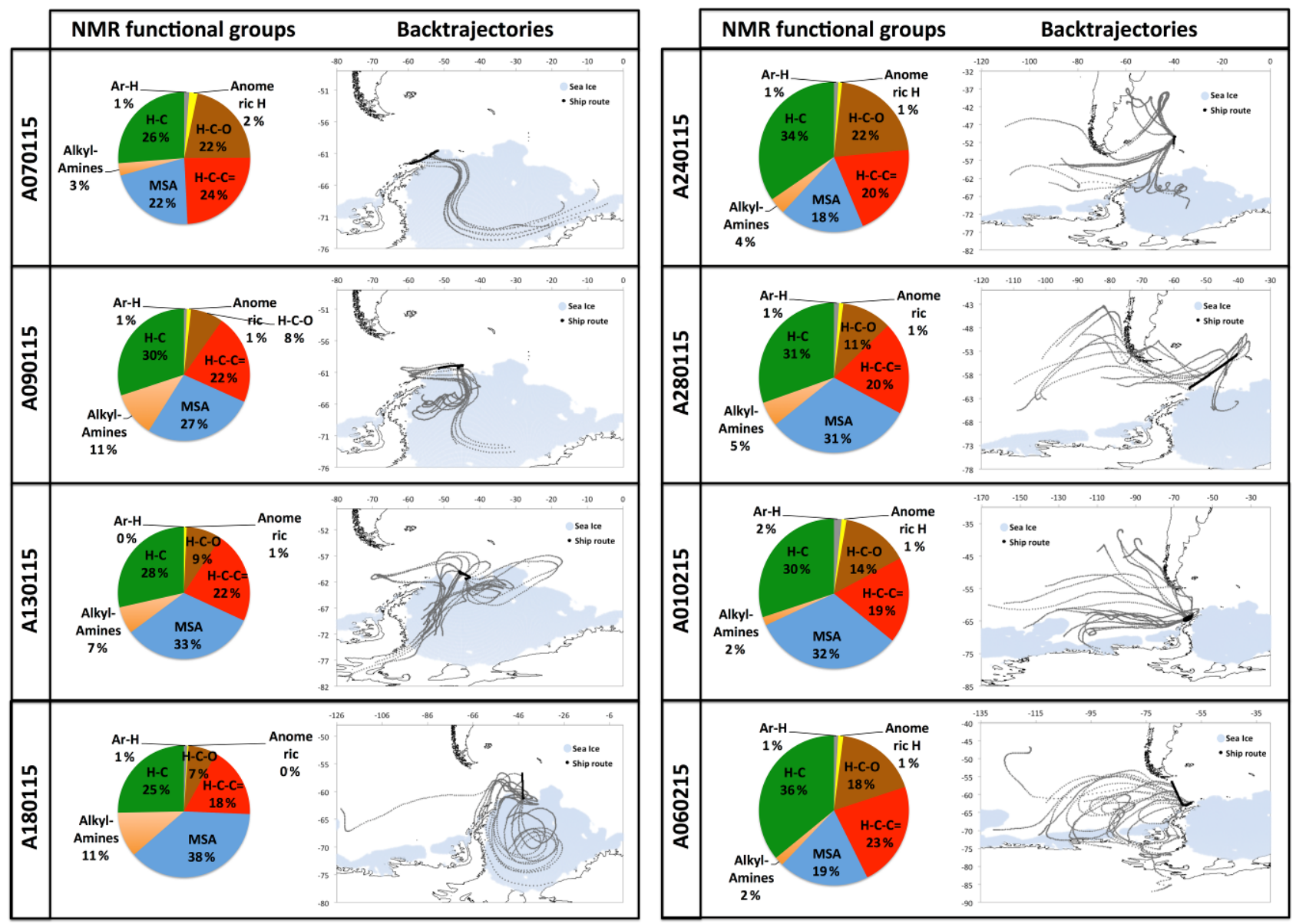

Figure 8. NMR functional group compositions of WSOC in the $\mathrm{PM}_{1}$ HiVol samples. Functionalities: $\mathrm{H}-\mathrm{C}(\mathrm{alkyls}), \mathrm{H}-\mathrm{C}-(\mathrm{C}=)$ (acyls), $\mathrm{H}-\mathrm{C}-\mathrm{O}$ (alcoxyl), MSA, amines, anomeric, and Ar-H (aromatic).

to creatinine, it must have occurred in source areas other than the algal blooms where we conducted the tank experiments, since we did not detect any creatinine in the aerosolized seawater and sea ice. Creatinine is a common metabolite of mammals; therefore an alternative source via the excreta of sea lions in Antarctic coastal areas can be postulated. However, a much more vast source in seawater is also possible under the hypothesis that creatinine results from the enzymatic conversion of creatine, which is a known metabolite of the urea cycle in marine animals (Whitledge and Dugdale, 1972) and phytoplankton (Allen et al., 2011) that contributes to pelagic DOC across the world's oceans (e.g., Wawrik et al., 2017).

\section{Conclusions}

Our results demonstrate that, beside MSA, a complex mixture of biogenic organic compounds contributes to the composition of submicron aerosol particles in the Antarctic atmosphere. Although individual organic markers encompassing sugars, amino acids, and carboxylic acids have been identi- fied in past studies, our results indicate that non-MSA biogenic organic compounds impact the bulk composition of organic aerosol in this environment (Fig. 8). The NMR analysis provides evidence for both secondary (more important in sympagic regions) and primary (more important in pelagic areas) marine sources. A third contribution from the terrestrial biota in the Antarctic Peninsula was also identified. The emission of sea-spray organics in offshore areas was unambiguously demonstrated by the determination of molecular tracers for lipids and polyols and by the comparison of the fine structures in the ${ }^{1} \mathrm{H}$-NMR spectra of the ambient samples and of the aerosol generated in the tank experiments. A new biogenic marker, creatinine, was identified for the first time in the ambient aerosol, extending the list of reduced nitrogen-containing molecular tracers in the atmosphere. The discovery of creatinine also exemplifies the usefulness of employing non-targeted analytical techniques like NMR spectroscopy for screening the organic composition of aerosol in remote environments where the sources of atmospheric particulate matter are still poorly understood. The complexity of organic composition illustrated in this study calls for more 
research on suitable methodologies - both online and offline, and combinations of them - to investigate the nature of nonMSA marine organic particles in offshore regions around the Antarctic continent.

Data availability. The NMR data sets are available on request to the corresponding author.

Supplement. The supplement related to this article is available online at: https://doi.org/10.5194/acp-20-4193-2020-supplement.

Author contributions. SD wrote the paper; MDO and RS coordinated the experimental activities in the field; MP, MDO, and SG collected the aerosol samples; MDO, MP, and DC collected the seaice samples; COD, JO, and DC set up the bubble-bursting tank; MR, MP, MR, NZ, and FV performed the sample extraction and preparation for WSOC and NMR analyses; NZ and MP performed the NMR analyses; SG and CJK carried out the HPLC/MS analyses; SD, MP, and ET elaborated on the NMR data; MDO, RS, and ET contributed to the interpretation of the analyses of the seawater samples; SD, MP, MR, MDO, TH, CJK, and ET contributed to the interpretation of the analyses of the aerosol samples; all authors contributed to the general discussion and the main conclusions of this study.

Competing interests. The authors declare that they have no conflict of interest.

Special issue statement. This article is part of the special issue "Marine organic matter: from biological production in the ocean to organic aerosol particles and marine clouds (ACP/OS inter-journal SI)". It is not associated with a conference.

Acknowledgements. The cruise was funded by the Spanish Ministry of Economy through projects PEGASO (CTM2012-37615) and Bio-Nuc (CGL2013-49020-R). The research leading to these results has received funding from the European Union's Seventh Framework Programme (FP7/2007-2013) Project BACCHUS under grant agreement no. 603445. The research activities of CNR were also supported by the project AirSEaLab: Progetto Laboratori Congiunti. We would like to thank Andrea Mazzanti for his advice in performing the NMR experiments at the NMR facility of the Dep. Industrial Chemistry, University of Bologna. We also thank David Beddows (University of Birmingham) for help in drawing figures, in particular air mass back-trajectories.

Financial support. This research has been supported by the European Commission (grant no. BACCHUS (603445)) and CNR project "AirSEaLab: Progetto Laboratori Congiunti".
Review statement. This paper was edited by Manuela van Pinxteren and reviewed by two anonymous referees.

\section{References}

Allen, A. E., Dupont, C. L., Obornik, M., Horak, A., Nunes-Nesi, A., McCrow, J. P., Zheng, H., Johnson, D. A., Hu, H., Fernie, A. R., and Bowler, C.: Evolution and metabolic significance of the urea cycle in photosynthetic diatoms, Nature, 473, 203-209, 2011.

Alpert, P. A., Ciuraru, R., Rossignol, S., Passananti, M., Tinel, L., Perrier, S., Dupart, Y., Steimer, S. S., Ammann, M., Donaldson, D. J., and George, C.: Fatty Acid Surfactant Photochemistry Results in New Particle Formation, Scientific Reports, 7, 12693, https://doi.org/10.1038/s41598-017-12601-2, 2017.

Barbaro, E., Zangrando, R., Vecchiato, M., Piazza, R., Cairns, W. R. L., Capodaglio, G., Barbante, C., and Gambaro, A.: Free amino acids in Antarctic aerosol: potential markers for the evolution and fate of marine aerosol, Atmos. Chem. Phys., 15, 5457-5469, https://doi.org/10.5194/acp-15-5457-2015, 2015.

Barbaro, E., Zangrando, R., Padoan, S., Karroca, O., Toscano, G., Cairns, W. R. L., Barbante, C., and Gambaro, A.: Aerosol and snow transfer processes: An investigation on the behavior of water-soluble organic compounds and ionic species, Chemosphere, 183, 132-138, 2017.

Bendle, J., Kawamura, K., Yamazaki, K., and Niwai, T.: Latitudinal distribution of terrestrial lipid biomarkers and n-alkane compound-specific stable carbon isotope ratios in the atmosphere over the western Pacific and Southern Ocean, Geochim. Cosmochim. Acta, 71, 5934-5955, 2007.

Bernard, F., Ciuraru, R., Boréave, A., and George, C.: Photosensitized Formation of Secondary Organic Aerosols Above the Air/Water Interface, Environ. Sci. Technol., 50, 8678-8686, 2016.

Bertram, H. C., Duus, J. Ø., Petersen, B. O., Hoppe, C., Larnkjaer, A., Schack-Nielsen, L,, Mølgaard, C., and Michaelsen, K. F.: Nuclear magnetic resonance-based metabonomics reveals strong sex effect on plasma metabolism in 17-year-old Scandinavians and correlation to retrospective infant plasma parameters, Metabolism Clinical and Experimental, 58, 1039-1045, 2009.

Cui, T., Green, H. S., Selleck, P. W., Zhang, Z., O’Brien, R. E., Gold, A., Keywood, M., Kroll, J. H., and Surratt, J. D.: Chemical characterization of isoprene- and monoterpene-derived secondary organic aerosol tracers in remote marine aerosols over a quarter century, ACS Earth Space Chem., 3, 935-946, 2019.

Dall'Osto, M., Ovadnevaite, J., Paglione, M., Beddows, D. C. S., Ceburnis, D., Cree, C., Cortés, P., Zamanillo, M., Nunes, S. O., Pérez, G. L., Ortega-Retuerta, E., Emelianov, M., Vaqué, D., Marrasé, C., Estrada, M., Montserrat Sala, M., Vidal, M., Fitzsimons, M. F., Beale, R., Airs, R., Rinaldi, M., Decesari, S., Facchini, M. C., Harrison, R. M., O'Dowd, C., and Simó, R.: Antarctic sea ice region as a source of biogenic organic nitrogen in aerosols, Scientific Reports, 7, 6047, https://doi.org/10.1038/s41598-017-06188-x, 2017.

Dall'Osto, M., Airs, R. L., Beale, R., Cree, C., Fitzsimons, M . F., Beddows, D., Harrison, R. M., Ceburnis, D., O'Dowd, C., Rinaldi, M., Paglione, M., Nenes, A., Decesari, S., and Simó, R.: Simultaneous detection of alkylamines in the surface ocean and 
atmosphere of the Antarctic sympagic environment, ACS Earth Space Chem., 3, 854-862, 2019.

Davison, B., Hewitt, C. N., D. O’Dowd, C., Lowe, J. A., Smith, M. H., Schwikowski, M., Baltensperger, U., and Harrison, R. M.: Dimethyl sulfide, methane sulfonic acid and physicochemical aerosol properties in Atlantic air from the United Kingdom to Halley Bay, J. Geophys. Res., 101, 22855-22867, 1996.

Decesari, S., Facchini, M. C., Fuzzi, S., and Tagliavini, E.: Characterization of water-soluble organic compounds in atmospheric aerosol: a new approach, J. Geophys. Res., 105, 1481-1489, 2000.

Decesari, S., Mircea, M., Cavalli, F., Fuzzi, S., Moretti, F., Tagliavini, E., and Facchini, M. C.: Source attribution of water-soluble organic aerosol by Nuclear Magnetic Resonance spectroscopy, Environ. Sci. Technol, 41, 2479-2484, 2007.

Draxler, R. R. and Rolph, G. D.: HYSPLIT (HYbrid Single-Particle Lagrangian Integrated Trajectory) Model access via NOAA ARL READY Website, available at: http://ready.arl.noaa.gov/ HYSPLIT.php (last access: March 2020), 2010.

Ezraty, R., Girard-Ardhuin, F., Piollé, J. F., Kaleschke, L., and Heygster, G.: Arctic and Antarctic sea ice concentration and Arctic sea ice drift estimated from Special Sensor Microwave data. Département d'Océanographie Physique et Spatiale, IFREMER, Brest, France and University of Bremen Germany, 2.1 edn, 2007.

Facchini, M. C., Decesari, S., Rinaldi, M., Carbone, C., Finessi, E., Mircea, M., Fuzzi, S., Moretti, F., Tagliavini, E., Ceburnis, D., and O'Dowd, C. D.: Important Source of Marine Secondary Organic Aerosol from Biogenic Amines, Environ. Sci. Technol., 42, 9116-9121, 2008.

Fossum, K. N., Ovadnevaite, J., Ceburnis, D., Dall'Osto, M., Marullo, S., Bellacicco, M., Simó, R., Liu, D., Flynn, M., Zuend, A., and O'Dowd, C.: Summertime primary and secondary contributions to Southern Ocean cloud condensation nuclei, Scientific Reports, 8, 13844, https://doi.org/10.1038/s41598-018-32047-4, 2018.

Frey, M. M., Norris, S. J., Brooks, I. M., Anderson, P. S., Nishimura, K., Yang, X., Jones, A. E., Nerentorp Mastromonaco, M. G., Jones, D. H., and Wolff, E. W.: First direct observation of sea salt aerosol production from blowing snow above sea ice, Atmos. Chem. Phys., 20, 2549-2578, https://doi.org/10.5194/acp20-2549-2020, 2020.

Fryxell, G. A. and Kendrick, G. A.: Austral spring microalgae across the Weddell Sea ice edge: spatial relationships found along a northward transect during AMERIEZ 83, Deep-sea Res., $35,1-20,1988$.

Ge, X., Wexler, A. S., and Clegg, S. L.: Atmospheric amines - Part II. Thermodynamic properties and gas/particle partitioning, Atmos. Environ., 45, 561-577, 2011.

Giordano, M. R., Kalnajs, L. E., Avery, A., Goetz, J. D., Davis, S. M., and DeCarlo, P. F.: A missing source of aerosols in Antarctica - beyond long-range transport, phytoplankton, and photochemistry, Atmos. Chem. Phys., 17, 1-20, https://doi.org/10.5194/acp17-1-2017, 2017.

Hertkorn, N., Harir, M., Koch, B. P., Michalke, B., and SchmittKopplin, P.: High-field NMR spectroscopy and FTICR mass spectrometry: powerful discovery tools for the molecular level characterization of marine dissolved organic matter, Biogeosciences, 10, 1583-1624, https://doi.org/10.5194/bg-10-15832013, 2013.
Kawamura, K., Seméré, R., Imai, Y., Fujii, Y., and Hayashi, M.: Water soluble dicarboxylic acids and related compounds in Antarctic aerosols, J. Geophys. Res., 101, 18721-18728, 1996.

Koprivnjak, J. F., Pfromm, P. H., Ingall, E., Vetter, T. A., SchmittKopplin, P., Hertkorn, N., Frommberger, M., Knicker, H., and Perdue, E. M.: Chemical and spectroscopic characterization of marine dissolved organic matter isolated using a coupled reverse osmosis-electrodialysis, Geochim. Cosmochim. Acta, 73, 42154231, 2009.

Kyrö, E.-M., Kerminen, V.-M., Virkkula, A., Dal Maso, M., Parshintsev, J., Ruíz-Jimenez, J., Forsström, L., Manninen, H. E., Riekkola, M.-L., Heinonen, P., and Kulmala, M.: Antarctic new particle formation from continental biogenic precursors, Atmos. Chem. Phys., 13, 3527-3546, https://doi.org/10.5194/acp13-3527-2013, 2013.

Li, S., Winters, H., Villacorte, L. O., Ekowati, Y., Emwas, A.-H. M., Kennedy, M. D., and Amy, G. L.: Compositional similarities and differences between transparent exopolymer particles (TEPs) from two marine bacteria and two marine algae: Significance to surface biofouling, Mar. Chem., 174, 131-140, 2015.

Liu, J., Dedrick, J., Russell, L. M., Senum, G. I., Uin, J., Kuang, C., Springston, S. R., Leaitch, W. R., Aiken, A. C., and Lubin, D.: High summertime aerosol organic functional group concentrations from marine and seabird sources at Ross Island, Antarctica, during AWARE, Atmos. Chem. Phys., 18, 85718587, https://doi.org/10.5194/acp-18-8571-2018, 2018.

Matulová, M., Husárová, S., Capek, P., Sancelme, M., and Delort, A. M.: Biotransformation of Various Saccharides and Production of Exopolymeric Substances by Cloud-Borne Bacillus sp. 3B6, Environ. Sci. Technol., 48, 14238-14247, 2014.

Nunes, S., Latasa, M., Delgado, M., Emelianov, M., Simó, R., and Etrada, M.: Phytoplankton community structure in contrasting ecosystems of the Southern Ocean: South Georgia, South Orkneys and western Antarctic Peninsula, Deep-Sea Res. I, 151, 103059, https://doi.org/10.1016/j.dsr.2019.06.005, 2019.

O'Dowd, C. D. and de Leeuw, G., Marine aerosol production: a review of the current knowledge. Philosophical Transactions of the Royal Society A: Mathematical, Phys. Eng. Sci., 365, 1753, https://doi.org/10.1098/rsta.2007.2043, 2007.

O’Dowd, C., Ceburnis, D., Ovadnevaite, J., Bialek, J., Stengel, D. B., Zacharias, M., Nitschke, U., Connan, S., Rinaldi, M., Fuzzi, S., Decesari, S., Facchini, M. C., Marullo, S., Santoleri, R., Dell'Anno, A., Corinaldesi, C., Tangherlini, M., and Danovaro, R.: Connecting marine productivity to sea-spray via nanoscale biological processes: Phytoplankton Dance or Death Disco?, Scientific Reports, 5, 14883, https://doi.org/10.1038/srep14883, 2015.

Oyamada, C., Kaneniwa, M., Ebitani, K., Murata, M., and Ishihara, K.: Mycosporine-like amino acids extracted from scallop (Patinopecten yessoensis) ovaries: UV protection and growth stimulation activities on human cells, Mar. Biotechnol., 10, 141150, 2007.

Passow, U.: Transparent exopolymer particles (TEP) in aquatic environments, Prog. Oceanogr., 55, 287-333, 2002.

Pautler, B. G., Woods, G. C., Dubnick, A., Simpson, A. J., Sharp, M. J., Fitzsimons, S. J., and Simpson, M. J.: Molecular characterization of dissolved organic matter in glacial ice: coupling natural abundance ${ }^{1} \mathrm{H}$ NMR and fluorescence spectroscopy, Environ. Sci. Technol., 46, 3753-3761, 2012. 
Prather, K. A., Bertram, T. H., Grassian, V. H., Deane, G. B., Stokes, M. D., DeMott, P. J., Aluwihare, L. I., Palenik, B. P., Azam, F., Seinfeld, J. H., Moffet, R. C., Molina, M. J., Cappa, C. D., Geiger, F. M., Roberts, G. C., Russell, L. M., Ault, A. P., Baltrusaitis, J., Collins, D. B., Corrigan, C. E., Cuadra-Rodriguez, L. A., Ebben, C. J., Forestieri, S. D., Guasco, T. L., Hersey, S. P., Kim, M. J., Lambert, W. F., Modini, R. L., Mui, W., Pedler, B. E., Ruppel, M. J., Ryder, O. S., Schoepp, N. G., Sullivan, R. C., and Zhao, D.: Bringing the ocean into the laboratory to probe the chemical complexity of sea spray aerosol, P. Natl. Acad. Sci. USA, 7, 7550-7555, 2013.

Repeta, D. J.: Chemical characterization and cycling of dissolved organic matter, in: Biogeochemistry of marine dissolved organic matter - second edition, edited by: Hansell, D. A. and Carlson, C. A., Elsevier 2015, ISBN 978-0-12-405940-5, 2014.

Rinaldi, M., Emblico, L., Decesari, S., Fuzzi, S., Facchini, M. C., and Librando, V.: Chemical characterization and source apportionment of size-segregated aerosol collected at an urban site in Sicily, Water Air Soil Pollut., 185, 311-321, https://doi.org/10.1007/s11270-007-9455-4, 2007.

Rintoul, S. R., Chown, S. L., DeConto, R. M., England, M. H., Fricker, H. A., Masson-Delmotte, V., Naish, T. R., Siegert, M. J., and Xavier, J. C.: Choosing the future of Antarctica, Nature, 558, 233-241, 2018.

Roukaerts, A., Cavagna, A.-J., Fripiat, F., Lannuzel, D., Meiners, K. M., and Dehairs, F.: Sea-ice algal primary production and nitrogen uptake off East Antarctica, Deep-Sea Res. II, 131, 140-149, https://doi.org/10.1016/j.dsr2.2015.08.007, 2016.

Schmale, J., Schneider, J., Nemitz, E., Tang, Y. S., Dragosits, U., Blackall, T. D., Trathan, P. N., Phillips, G. J., Sutton, M., and Braban, C. F.: Sub-Antarctic marine aerosol: dominant contributions from biogenic sources, Atmos. Chem. Phys., 13, 86698694, https://doi.org/10.5194/acp-13-8669-2013, 2013.

Schmitt-Kopplin, P., Liger-Belair, G., Koch, B. P., Flerus, R., Kattner, G., Harir, M., Kanawati, B., Lucio, M., Tziotis, D., Hertkorn, N., and Gebefügi, I.: Dissolved organic matter in sea spray: a transfer study from marine surface water to aerosols, Biogeosciences, 9, 1571-1582, https://doi.org/10.5194/bg-91571-2012, 2012.

Schwier, A. N., Rose, C., Asmi, E., Ebling, A. M., Landing, W. M., Marro, S., Pedrotti, M.-L., Sallon, A., Iuculano, F., Agusti, S., Tsiola, A., Pitta, P., Louis, J., Guieu, C., Gazeau, F., and Sellegri, K.: Primary marine aerosol emissions from the Mediterranean Sea during pre-bloom and oligotrophic conditions: correlations to seawater chlorophyll $a$ from a mesocosm study, Atmos. Chem. Phys., 15, 7961-7976, https://doi.org/10.5194/acp15-7961-2015, 2015.
Suzuki, Y., Kawakami, M., and Akasaka, K.: ${ }^{1} \mathrm{H}$ NMR application for characterizing water-soluble organic compounds in urban atmospheric particles, Environ. Sci. Technol., 35, 2656-2664, 2001.

The IMBIE team: Mass balance of the Antarctic ice sheet from 1992 to 2017, Nature, 558, 219-222, https://doi.org/10.1038/s41586018-0179-y, 2018.

Upadhyay, D., Umaa, S., Govind, M., and Naranamangalam, J.: Role of NMR metabonomics in Celiac Disease (CeD), Biomedical Spectroscopy and Imaging, 5, 27-40, 2016.

Virkkula, A., Teinilä, K., Hillamo, R., Kerminen, V.-M., Saarikoski, S., Aurela, M., Viidanoja, J., Paatero, J., Koponen, I. K., and Kulmala, M.: Chemical composition of boundary layer aerosol over the Atlantic Ocean and at an Antarctic site, Atmos. Chem. Phys., 6, 3407-3421, https://doi.org/10.5194/acp-6-3407-2006, 2006.

Wawrik, B., Bronk, D. A., Baer, S. E., Chi, L., Sun, M., Cooper, J. T., and Yang, Z.: Bacterial utilization of creatine in seawater, Aquat. Microb. Ecol., 80, 153-165, 2017.

Whitledge, T. E. and Dugdale, R. C.: Creatine in seawater, Limnol. Oceanogr., 17, 309-314, 1972.

Willis, M. D., Köllner, F., Burkart, J., Bozem, H., Thomas, J. L., Schneider, J., Aliabadi, A. A., Hoor, P. M., Schulz, H., Herber, A. B., Leaitch, R., and Abbatt, J. P. D.: Evidence for marine biogenic influence on summertime Arctic aerosol, Geophys. Res. Lett., 44, 6460-6470, https://doi.org/10.1002/2017GL073359, 2017.

Willis, M. D., Leaitch, W. R., and Abbatt, J. P. D.: Processes controlling the composition and abundance of Arctic aerosol, Rev. Geophys., 56, 621-671, 2018.

Zamanillo M., Ortega-Retuerta, E., Nunes, S., Estrada, M., Sala, M. M., Royer, S.-J., López-Sandoval, D. C., Emelianov, M., Vaqué, D., Marrasé, C., and Simó, R.: Distribution of transparent exopolymer particles (TEP) in distinct regions of the Southern Ocean, Sci. Total Environ., 691, 736-748, https://doi.org/10.1016/j.scitotenv.2019.06.524, 2019.

Zorn, S. R., Drewnick, F., Schott, M., Hoffmann, T., and Borrmann, S.: Characterization of the South Atlantic marine boundary layer aerosol using an aerodyne aerosol mass spectrometer, Atmos. Chem. Phys., 8, 4711-4728, https://doi.org/10.5194/acp-8-47112008, 2008. 